\title{
FRACTAL ANALYSIS OF THE DISTRIBUTION OF CAVE LENGTHS IN SLOVENIA
}

\author{
FRAKTALNA ANALIZA PORAZDELITVE DOLŽIN JAM V \\ SLOVENIJI
}

\author{
Timotej VERBOVŠEK ${ }^{1}$
}

\begin{abstract}
UDC 551.435.84:51-7

Timotej Verbovšek: Fractal analysis of the distribution of cave lengths in Slovenia

The lengths of the Slovenian caves follow the power-law distribution through several orders of magnitude, which implies that the caves can be considered as natural fractal objects. Fractal dimensions obtained from distribution of all caves are about 1.07 , and vary within different tectonic and hydrogeological units. Some deviations from the ideal best fit line in log-log plots (i.e. lower and upper cut-off limits) can be explained by underestimation, as many very short caves are not registered. The study of tectonic and hydrogeological setting indicates that the greatest dimensions occur in the rocks with karstic-fracture and fracture porosity and the lowest in low-permeability rocks. Proximity to major tectonic structures shows a detectable effect on the cave length distribution, and the influence is greatest for the caves closer to the faults and thrust fronts. Dimensions are lower than those of fracture networks and faults, which can be most probably explained by flow channeling along the fracture networks, which causes the decrease of fractal dimension. The physical causes of power law scaling and variations in fractal dimensions (power law exponents) are still poorly understood, but the behaviour of fracture networks is believed to be caused by a scale-independent fractal fragmentation of the blocks, and during the process of forming the caves inherit some fractal geometrical properties of the networks.
\end{abstract}

Key words: cave length, fractal dimension, Slovenia, karst hydrogeology.

\section{Izvleček}

UDK 551.435.84:51-7

Timotej Verbovšek: Fraktalna analiza porazdelitve dolžin jam v Sloveniji

Dolžina jam v Sloveniji je porazdeljena po potenčnem zakonu, ki je značilen za fraktalne objekte. Fraktalna dimenzija jam se giblje okoli vrednosti 1.07 in se spreminja glede na tektonsko in hidrogeološko okolje. Odstopanja od idealne premice nastanejo zaradi podcenjenega števila jam, saj je krajših jam več, kot jih je dejansko zabeleženih. Analiza tektonskega in hidrogeološkega okolja kaže, da so najvišje vrednosti fraktalne dimenzije značilne za kamnine s kraško-razpoklinsko in razpoklinsko poroznostjo ter najnižje za slabo prepustne kamnine. Bližina tektonskih struktur zelo vpliva na porazdelitev dolžin jam, vpliv pa je večji pri jamah, ki ležijo bližje prelomom in narivom. Vrednosti dimenzij jam so manjše kot dimenzije mrež razpok ali prelomov, najverjetneje zaradi koncentriranja tokov (kanalskih efektov) po mrežah razpok, kar posledično zmanjša fraktalno dimenzijo. Fizikalni vzroki, ki povzročajo potenčno odvisnost in variacije fraktalnih dimenzij (eksponentov potenčnega zakona), so še vedno delno nepojasnjeni. Vseeno pa lahko nastanek mrež razpok pripišemo fraktalni fragmentaciji kamnin, ki deluje neodvisno od merila, jame pa nato ob nastajanju podedujejo določene fraktalne lastnosti razpok.

Ključne besede: dolžina jam, fraktalna dimenzija, Slovenija, kraška hidrogeologija.

\footnotetext{
${ }^{1}$ University of Ljubljana, Faculty of Natural Sciences and Engineering, Department of Geology, Aškerčeva 12, Ljubljana, Slovenia phone: +3861 4704644, fax: +38614704560, e-mail: timotej.verbovsek@guest.arnes.si
}

Received/Prejeto: 01.10.2007 


\section{INTRODUCTION}

Fractals are defined as geometric objects with a self-similar property, which implies that they do not change their shape with scale (Feder, 1988). This statement is valid only for strictly self-similar mathematical fractals, like Koch curve or Sierpinski carpet. One should note that natural fractals differ from the ideal ones, as although they appear self-similar or self-affine at some scales, there always exist a natural lower and upper cut-off scale, and fractal analyses of these objects are valid only within these two values. Fractal approaches are appropriate where classical geometry is not suitable for describing the irregular objects found in nature. Generally these cannot be modelled by easily-defined mathematical objects - for example the "clouds are not spheres, mountains are not cones, coastlines are not circles, and bark is not smooth, nor does lightning travel in a straight line" (Mandelbrot, 1983). The fundamental property of fractals is their fractal dimension (D), which represents the ability of an object to fill the space (in one, two or three dimensions). It can occupy non-integer values, compared to the integer values characteristic of Euclidean objects, such as 3-D cubes or 2-D planar surfaces. As an example, an object with a fractal dimension of 1.4 exhibits properties of both 1-D and 2-D objects, as it fills the more space than a line $(\mathrm{D}=1)$ and less space than a surface $(\mathrm{D}=2)$.
The caves form during the selective enlargement of fractures, bedding planes, faults and other discontinuities in the soluble rock and only a few presolutional openings develop in larger passages (Palmer, 1991, Ford \& Williams, 2007). The degree of a cave to fill the neighboring rocks can be described quantitatively with the fractal dimension D. Both caves (Curl, 1999) and consequently cave lengths (Laverty, 1987) have been found to exhibit fractal properties. A study of Curl (1966) was performed for distribution of cave lengths and the number of entranceless for the "proper caves" - those of accessible size including those with no entrances. However, the influences of different lithologic properties, hydrogeologic and tectonic settings on the distribution of cave lengths have not been yet discussed in detail.

The goal of this paper is to analyze and discuss the distribution of lengths of the caves in Slovenia in different tectonic and hydrogeological environments plus the influence of the distance of the caves to the most obvious tectonic structures. As already noted by Curl (1986), the fractal interpretations probably do not directly reveal any details about geomorphic processes responsible for the distribution of lengths of caves, but this distribution does contain information about the geometry of caves and possibly constrains ideas about geomorphic processes.

\section{MATERIALS AND METHODS}

Three different influencing factors on the cave length distribution were studied, as mentioned above (tectonic and hydrogeological position plus the distance to the major tectonic structures). The data for 7552 caves were analyzed (spatial coordinates in the national Gauss-Krueger system and cave lengths), as recorded in the national cave register. The lengths are based on survey lengths, as recorded in the register. There exist many other ways of measuring cave lengths besides classical survey, including 3-D measurements with spherical linked modular elements (Curl, 1986; 1999) and measuring in 2-D plane (plan length) instead of performing classical total survey lengths in all three dimensions (Laverty, 1987). Nevertheless, regardless on method used, cave lengths distribution exhibits fractal properties. Also, as caves are usually long compared to passage breadth, the classical approach is acceptable. Unfortunately there exists no data on surveying method in the register, so the length values are taken directly from register. This approach is similar to the one of Curl (1966), where if the length of a cave was only stated in the report, this value was used. An important factor which can affect the results of analyzed cave lengths is the number of entranceless caves, studied in detail by Curl (1966). The number of entranceless caves in Slovenia is not known, but probably it is high, as predicted by Curl. However, he noticed that the average lengths of entranceless caves are more like those of caves with one or more entrances than like the predicted average length of entranceless caves. Therefore the effect on the greater number of entranceless caves should be uniformly distributed along a complete cumulative curve of cave lengths and should not affect the shape of the curve, but should only shift it upwards.

The register was imported into relational database program (MS Access) and the data was further analyzed with GIS and statistical software. Some basic statistics were also calculated, such as minimum and maximum length and median. The median was used instead of mean or geometric mean, as the data does not follow neither normal nor lognormal distribution. 
For the determination of tectonic setting, the structural-tectonic map of Slovenia (Poljak, 2000) was digitized into a GIS shape file and the tectonic unit names were assigned to polygons. Caves belonging to a selected polygon (i.e. tectonic unit) were consequently selected from the complete dataset. For the determination of hydrogeologic setting, the shape file with the polygons of different hydrogeological units was obtained from the EuroWaterNet project website (http://nfp-si.eionet.eu.int/ ewnsi), and the process of grouping the caves was similar to the grouping into tectonic units. The major faults and thrust fronts were digitized from the same structural-tectonic map (Poljak, 2000) and using the GIS software the caves were grouped into three classes $( \pm 150 \mathrm{~m}, \pm 250 \mathrm{~m}$ and $\pm 500 \mathrm{~m}$ ), whether they fell into the $300 \mathrm{~m}, 500 \mathrm{~m}$ or $1000 \mathrm{~m}$ wide belt around the fault or thrust front.
Subsequently the relationship between the numbers of caves $\mathrm{N}$ in the specific setting with length greater than $\mathrm{L}$ was established, and the correlations were inspected in the log-log plots. For example, caves belonging only to the tectonic unit of External Dinarides were selected as explained in the former paragraph, and their distribution was analyzed in the following way. According to equation $D=\log N(s) / \log L$ (Bonnet et al., 2001), the fractal dimension $\mathrm{D}$ was calculated as the negative slope of the linear regression best-fit line of $\log N-\log L$ plot. The process of calculation of D was repeated for all other caves belonging to different units or groups of distance to the major tectonic structures. The number of steps for the lengths interval was chosen as the power of $2(1,2,4$, 8 ...), with some major additional steps in between (10, 50,100 etc).

\section{RESULTS}

\section{TECTONIC SETTING}

Caves were grouped into seven tectonic units according to their location in the structural-tectonic map (Placer, 1999; Poljak, 2000; Fig. 1). With minor deviation in the left-hand side of the plot, cave lengths follow power law distribution (linear line in log-log plot), characteristic for fractal behaviour. The median values of lengths (Tab. 1) are quite similar, except for the group of Adriatic foreland, and have the value around $23 \mathrm{~m}$.

The fractal dimensions enable more appealing insight into the cave length properties than the classical statistical approach using the median or other statistics, and they vary among the tectonic units (Tab. 1). All results exhibit a very high value of $R^{2}$. Note that the values of $D$ and $\mathrm{R}^{2}$ in the table are valid only for the linear part, not for the complete curve. The lowest values can be found in the tectonic units of Periadriatic igneous rocks and Internal Dinarides, and the highest in the unit of External Dinarides and also in Southern Alps. The discussion of the results is given in the next section. The number of analyzed caves $(\mathrm{N}=9)$ in the Adriatic foreland is too small to comment reliably, and deviations of the curve can be also seen in the plot (Fig. 2), so the D could not be calculated.

\section{HYDROGEOLOGIC SETTING}

Similar behaviour of cave length distribution can be observed in the plot (Fig. 4) for the different hydrogeological units (Fig. 3). The highest values (Tab. 2) are found in aquifers with karstic and fracture porosity and those with fracture porosity $(D=1.06)$ and lowest in the aquifers and beds with intergranular porosity $(\mathrm{D}=0.87, \mathrm{D}=0.86)$. Deviations occur only for the group "Beds with low porosity", as D is greater than expected, about 1.08 . This curve does not show such a linear trend as the others, and the number of the data is much smaller.

\section{DISTANCE TO THE MAJOR TECTONIC STRUCTURES}

Caves were grouped into three classes $( \pm 150 \mathrm{~m}, \pm 250 \mathrm{~m}$ and $\pm 500 \mathrm{~m}$ ), whether they fell into the $300 \mathrm{~m}, 500 \mathrm{~m}$ or $1000 \mathrm{~m}$ wide belt around the fault or thrust front (Fig. 5), as shown on the structural-tectonic map (Poljak, 2000). Similar behaviour of general cave length distribution as for the tectonic and hydrogeological units can be observed in the plot for the three groups, as the lengths follow a linear fit line in the log-log plots. The median values are similar, approximately $23 \mathrm{~m}$. As for the tectonic units, the units with higher $\mathrm{D}$ contain longer caves, which is reasonable for those caves with fractal dimension larger than one compared to those with $\mathrm{D}$ lower than one.

Nevertheless, a gap of number of caves occurs in the right-hand side of all three plots (Fig. 6), for example at L $=3000 \mathrm{~m}(\log \mathrm{L}=3.5)$ for the $\pm 150 \mathrm{~m}$ distance group. This indicates that the number of caves long about $3000 \mathrm{~m}$ is much lower than in case where all the caves are considered regardless of distance to the faults. The influence of the tectonic structures is greater when the caves are closer to the structures, as the gap is more noticeable for the $\pm 150 \mathrm{~m}$ group and slowly disappears towards the $\pm 500 \mathrm{~m}$ group. 

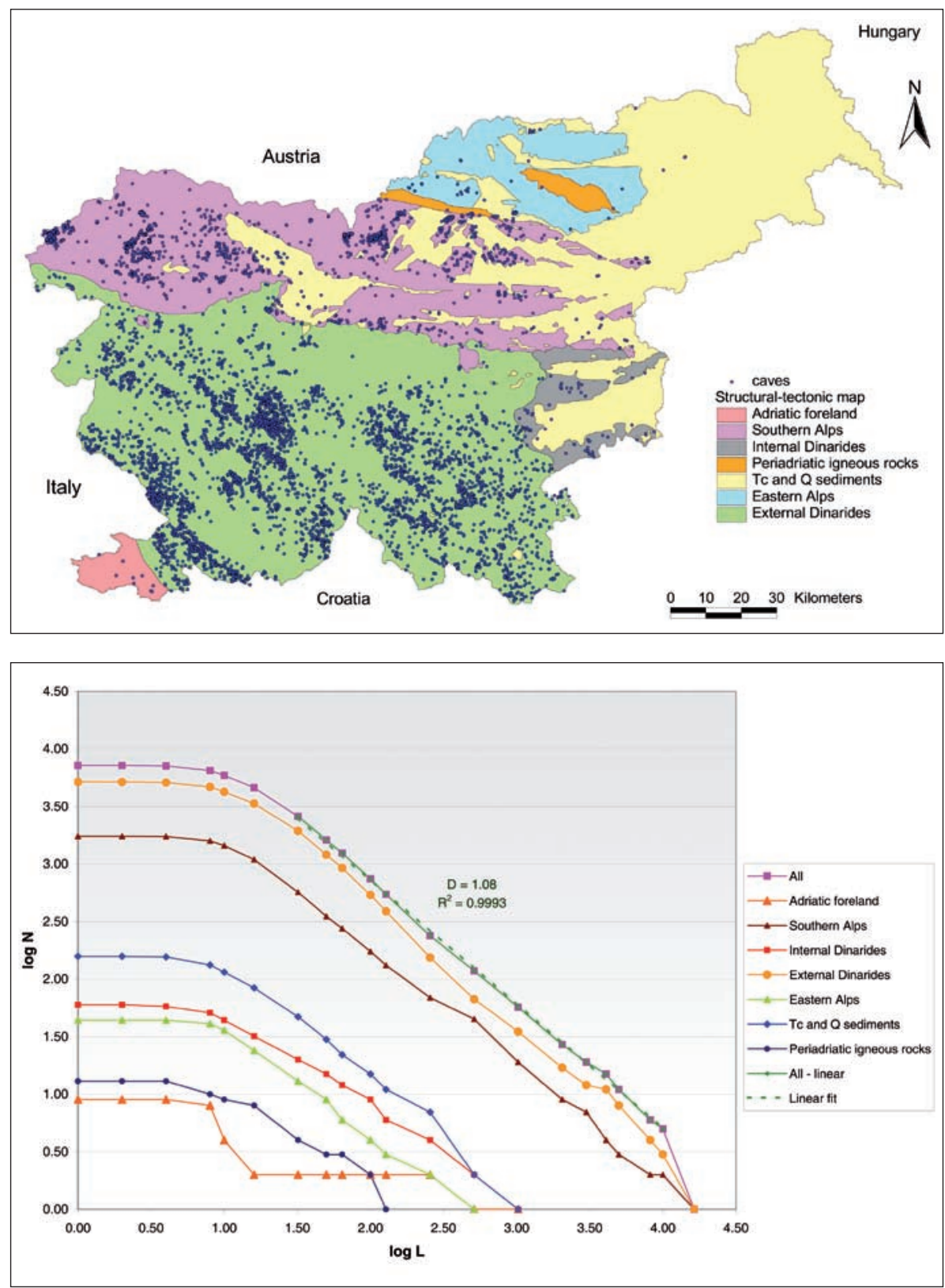

Fig. 1: Structural-tectonic setting of the caves
Fig. 2: Log-log distribution plot for the number of caves $(N)$ longer than a specific length (L) in different tectonic settings

Tab. 1: Results for fractal dimension of cave lengths in different tectonic units ( $D=$ fractal dimension, $R^{2}=$ coefficient of determination, $N=$ number of caves. The same notation is valid for the Tab. 2.

\begin{tabular}{lllllll}
\hline Tectonic setting & $\mathbf{D}$ & $\mathbf{R}^{2}$ & $\mathbf{N}$ & median & min & max \\
\hline Adriatic foreland & - & - & 9 & 10.0 & 5 & 876 \\
\hline Southern Alps & 1.00 & 0.9974 & 1744 & 21.5 & 1 & 10870 \\
\hline Internal Dinarides & 0.74 & 0.9934 & 60 & 20.0 & 4 & 1726 \\
\hline External Dinarides & 1.10 & 0.9970 & 5166 & 24.0 & 1 & 19555 \\
\hline Eastern Alps & 0.92 & 0.9940 & 44 & 18.0 & 5 & 2057 \\
\hline Tc and Q sediments & 0.89 & 0.9950 & 158 & 18.5 & 3 & 1300 \\
\hline Periadriatic igneous rocks & 0.60 & 0.9741 & 13 & 20.0 & 7 & 205 \\
\hline Total & $\mathbf{1 . 0 8}$ & $\mathbf{0 . 9 9 9 3}$ & $\mathbf{7 1 9 4}$ & $\mathbf{2 3 . 0}$ & $\mathbf{1}$ & $\mathbf{1 9 5 5 5}$ \\
\hline
\end{tabular}



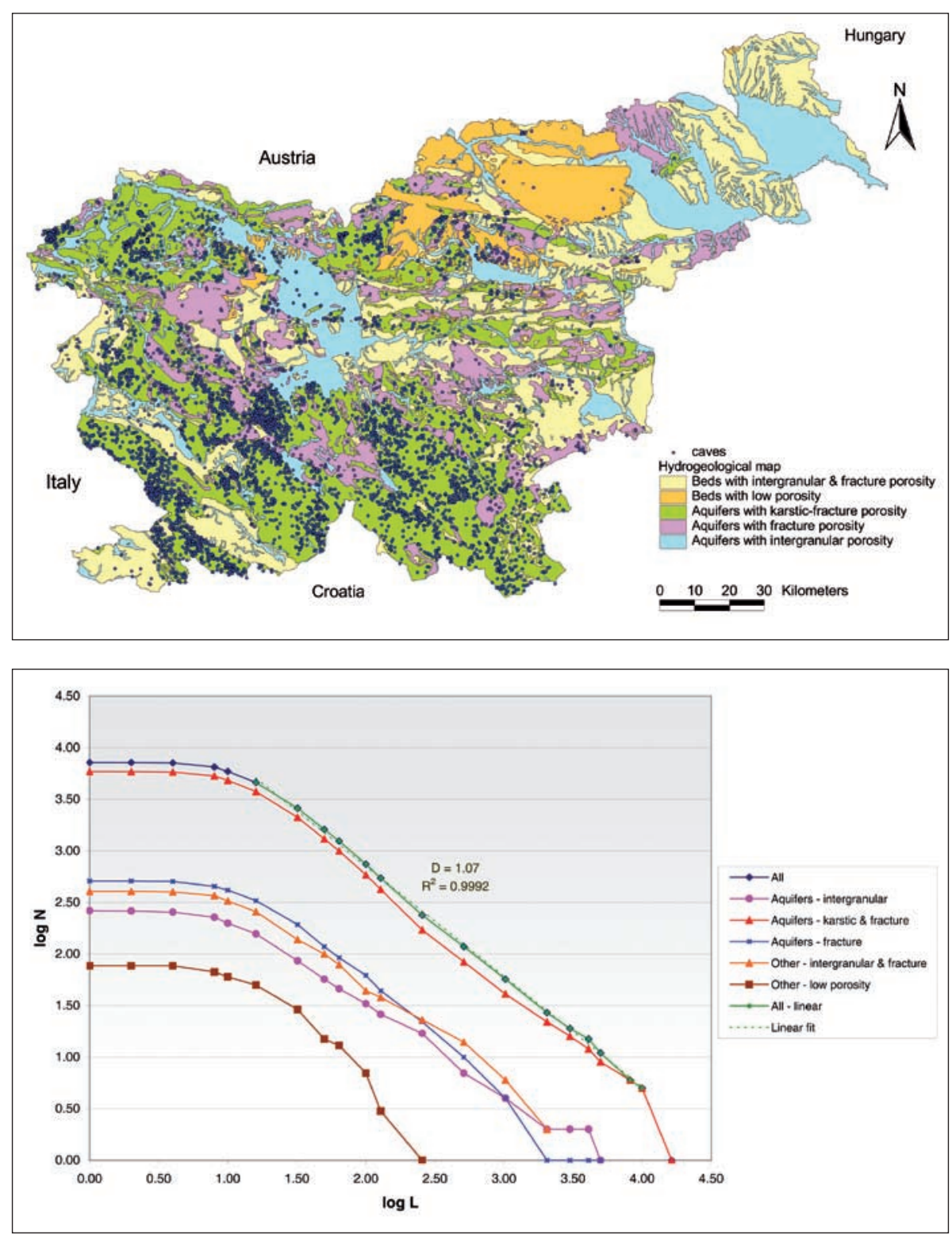

Tab. 2: Results for fractal dimension of cave lengths in different hydrogeological environments

\begin{tabular}{lllllll}
\hline Hydrogeologic setting & $\mathbf{D}$ & $\mathbf{R}^{2}$ & $\mathbf{N}$ & median & $\min$ & $\max$ \\
\hline Aquifers with intergranular porosity & 0.87 & 0.9957 & 263 & 20.0 & 2 & 8057 \\
\hline Aquifers with karstic-fracture porosity & 1.06 & 0.9975 & 5872 & 23.0 & 1 & 19555 \\
\hline Aquifers with fracture porosity & 1.06 & 0.9954 & 510 & 24.5 & 4 & 5800 \\
\hline Beds with intergranular \& fracture por. & 0.86 & 0.9943 & 404 & 23.0 & 3 & 2780 \\
\hline Beds with low porosity & 1.08 & 0.9852 & 77 & 25.0 & 7 & 1159 \\
\hline Total & $\mathbf{1 . 0 7}$ & $\mathbf{0 . 9 9 9 1}$ & $\mathbf{7 1 2 6}$ & $\mathbf{2 3 . 0}$ & $\mathbf{1}$ & $\mathbf{1 9 5 5 5}$ \\
\hline
\end{tabular}

Fig. 3: Hydrogeological setting of the caves

Fig. 4: Log-log distribution plot for the number of caves $(N)$ longer than a specific length (L) in different hydrogeological settings 


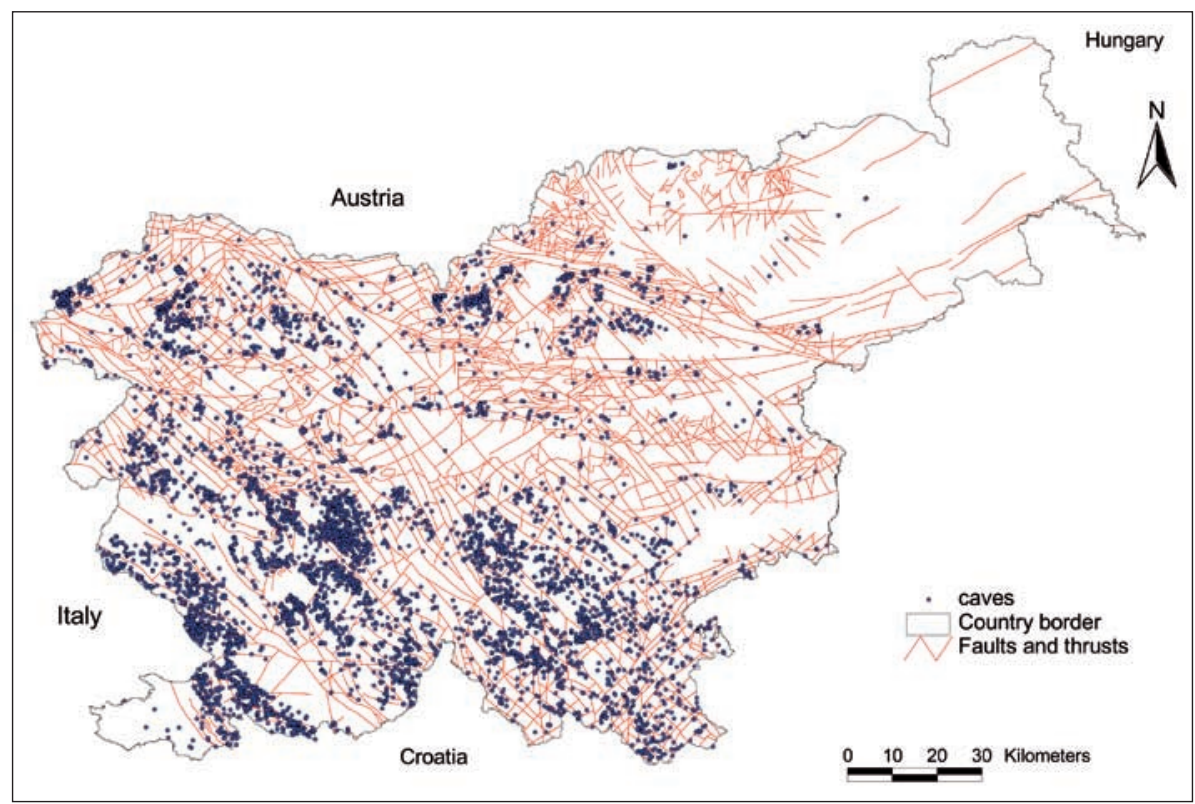

Fig. 5: Settings of the caves according to distance to the major faults and thrust fronts

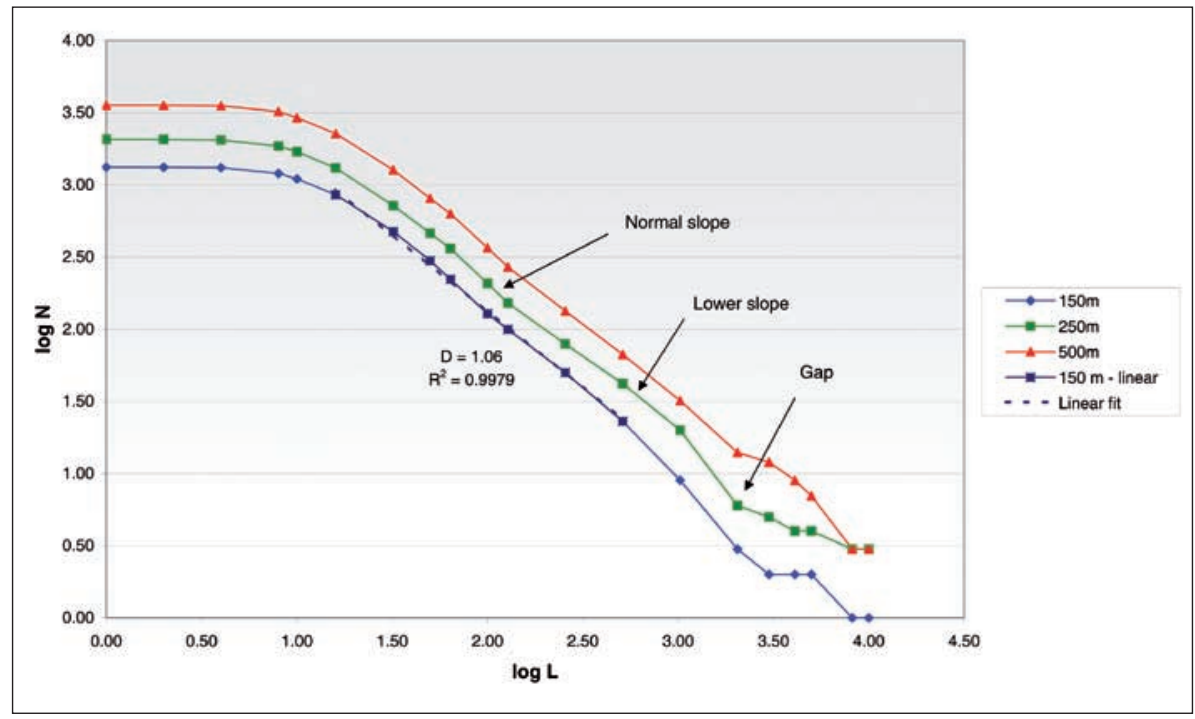

Fig. 6: Log-log distribution plot for the number of caves $(N)$ longer than a specific length $(L)$ in three groups of distance to the major tectonic structures 


\section{DISCUSSION AND CONCLUSIONS}

Cave length distribution can be described as fractal. Remarkably similar behaviour of curves in the plots is observed, as a linear plot of number of caves, longer than specific length in the log-log plots. The fractal approach provides a better insight into the cave geometry by analyzing the fractal dimension $\mathrm{D}$ instead of median or other common statistics values.

The fractal dimension calculated from the distributions can not be directly interpreted as a fractal dimension of the caves themselves, i.e. used as a direct measurement of the geometry of the caves, as these two dimension are obtained in a different way. The first one is calculated as a negative slope of the distribution of cave lengths, and the second one is usually obtained by a Richardson's (yardstick) or box-counting method (Feder, 1988). However, these distributions probably have a natural source, and the differences between the fractal dimensions are clearly observable, as discussed below.

The lowest values can be found in the tectonic units of Periadriatic igneous rocks and Internal Dinarides, which are comprised mostly of low-porosity and especially of low-permeability rocks. The highest fractal dimensions $(D=1.10)$ appear in the unit of External Dinarides. This unit is represented mostly by carbonates of Dinaric carbonate platform, which are intensely fractured and karstified. Similar explanation is valid for the unit of Southern Alps $(D=1.00)$, also consisting of karstified and fractured carbonates. The number of analyzed caves $(\mathrm{N}=9)$ in the Adriatic foreland is too small to comment reliably, and deviations of the curve can be also seen in the plot (Fig. 2 ), so the D could not be calculated. The rocks represented in this unit are clastic (flysch) sediments, and caves occur in the relatively thin-bedded layers of calcarenite. Value of D in Tertiary and Quaternary sediments is lower than one, which can indicate that the caves formed in this unit could resemble objects with geometries between a point and a line, and not the branching channels with $\mathrm{D}$ higher than one. The fractal dimension closer to zero resembles point-like objects, the one closer to one linear objects and the one closer to two planar-filling objects. Values of D lower than one are therefore possible, as dimension is obtained from the distribution and not from the geometric properties of the caves. Another explanation for the lower values of $\mathrm{D}$, although less possible, could be found in the surveying method, as the caves are usually surveyed by classical linear method. One should be therefore very careful when applying the results for fractal dimension obtained from the length distribution to geometric properties of the caves. Nevertheless, the value of dimension less than one clearly indicates that these cave lengths are different from the ones with the higher dimension, and interpretation of these values is still possible by fractal methods. The fractal dimension is lower in less soluble and less erodable rocks, like igneous rocks $(D=0.60)$ or rocks of Internal Dinarides $(\mathrm{D}=0.74)$, which were affected by lower degree of fracturing and have generally lower permeability than the igneous rocks. The lowest values are found in Periadriatic group. The hardness of these rocks is greater compared to the others, and consequently they are hard to erode (Kusumayudha et al., 2000), so the cave passages cannot develop in such extent as in more soluble carbonates or clastic rocks.

Similar to the explanation of tectonic setting, the higher D for hydrogeologic setting could correspond to the rocks having been affected by fractal fracturation and subsequent dissolution along the fracture networks. The highest values (Tab. 2) are found in aquifers with karstic and fracture porosity and those with fracture porosity $(\mathrm{D}=1.06)$ and lowest in the aquifers and beds with intergranular porosity $(\mathrm{D}=0.87, \mathrm{D}=0.86)$. Deviations occur only for the group "Beds with low porosity", as D is greater than expected, about 1.08. Possible explanation is that rocks with quite different hydrogeological and lithological properties occur within this group, which influences the fractal dimension.

The vicinity of tectonic structures therefore has a noticeable effect on cave length distribution, and this can be most likely interpreted as tectonic dissection of longer caves into shorter ones, and the tectonic effects can be manifested by displacement or collapse of the caves. This effect is also seen on the middle part of the plot (to the left side of the gap), where a lower slope indicates the greater number of shorter caves, which are uniformly distributed along the line. Some points in this part lie higher above the linear fit line than expected and these represent the increased number of shorter caves, which form by fragmentation of the longer ones. The deposited cave sediments can also influence the results, as these obstruct the traversable passages and can therefore divide the cave into smaller segments. However, this process could hardly be seen on the cumulative distribution plot for all caves, as the effect is more or less random and should thus be distributed along the complete plot and in addition it should not be influenced by distance to the tectonic structures.

The fractal dimension obtained from the distribution of all caves is about 1.07 and varies among different tectonic and hydrogeological units. The usual explanation of fractal dimension $\mathrm{D}$ higher than 1 indicates that caves with such dimension fill more space than those with ideal dimension of 1.00 (for example a straight line), and the geological constraints limit the dimension to be lower 
than 2. This is strictly true for dimensions calculated by Richardson's or box-counting methods, and possibly not directly applicable to the ones obtained by distribution analysis, though the results are in very good agreement with the other studies, as follows. Kusumayudha et al. (2000) obtained the dimension $\mathrm{D}=1.04-1.08 \pm 0.01$ for caves in different lithologic environments in Indonesia and have used the box-counting method. Šušteršič (1983) calculated the value of $\mathrm{D}=1.08$ for the cave Dimnice in Slovenia by Richardson's (yardstick) method and similar approach was used by Laverty (1987), who noted that cave length exhibits fractal behaviour with dimensions between 1.0 and 1.5 for caves in Sarawak and Spain. Fractal dimension based on calculation from the distribution was determined by Curl (1986), who calculated a slightly higher value $\mathrm{D}=1.4$ than in this study for caves in different environments. The differences from the analyses of Curl (1986) can be attributed to the facts that in his study only the caves in limestone, marble and magnesitic limestone were analyzed and those in dolomite, insoluble rock and gypsum were excluded. The dimensions are valid for the caves situated in specific regions in the USA, and the two exceptions from these values are found in the Austrian and Irish limestones. The geological, hydrological and tectonic settings certainly influence the distributions, but there is no available data to precisely compare the effects of the different environments.

The fractal behaviour of cave lengths distribution can be possibly explained as the dissolution occurs along the fractures, bedding planes, faults and other discontinuities in the soluble rock. It is well known that fracture networks are fractal, and their dimension in $2 \mathrm{D}$ varies from around 1.3 to 1.7 (Bonnet et al., 2001). Faults are also fractal objects with rather lower dimensions, around $1.0-1.5$. Results of this study show that the cave lengths distributions exhibit lower dimensions $(\mathrm{D}=1.08)$ than the faults or the fracture networks. Although the dimensions can not be directly compared, lower values can be explained by channeling of flow through the fracture networks and especially bedding planes, which serve as pathways for the water. It has been observed that when a preferential way is dissolved through the network, the flow increases due to larger channels, the obliteration of irregular shape of the channel by erosion is faster and consequently the fractal dimension therefore decreases with larger flow rates (Kusumayudha et al., 2000).

The lower slope of the distribution curves on the left-hand side of the plots can be explained by undersampling (Villemin et al., 1995), as below some threshold values the number of caves is underestimated. Similar trends were observed by three different studies. Curl (1966) analyzed the cave lengths, where for the observed curves for natural data, the left part of the plots exhibited a lower slope and the modeled curves showed much uniform slope. He also noted for his data, that the cumulative distributions should be smoother if enough accurate data were available and all caves were considered. Loucks (1999) observed this effect for the cave widths, where deviations appeared for width below a threshold of few meters. Finally, Villemin et al. (1995) noticed this effect for fault lengths. The caves with lengths lower than few meters are merely not considered as caves (they are not recorded in the register), and thus their number is much higher in the nature than actually recorded. The problem of cave definition can be raised here and was already discussed by Curl (1986). Generally the cave is regarded as such if it is traversable by humans. Cave spaces evidently exist at all scales, but are not registered, and these voids in the rocks are present from microns to hundreds of meters (Curl, 1999). The number of caves $\mathrm{N}$ with length about $1 \mathrm{~m}$ should thus be much higher, around 107,000 and not around 7,200 as seen from example of the "all units" in the Fig. 1. This number can be simply estimated by inserting the value of $\mathrm{L}=1 \mathrm{~m}$ into the best linear-fit equation $\log N=1.082 * \log L+5.029$ for "all units". This is only a quick estimation, as the entranceless caves are not considered in this study due to the lack of data in the register. The graph could also be extended to a much lower scale (farther to the left), and the rock porosity (dissolution, fenestral, vug) can be also interpreted as a "cave", but obviously not traversable by humans. Extrapolation to the "longer" side is contrarily not possible, as in this case the number of caves becomes less than one, and the curve also rapidly deviates from the linear fit line. Similar observations were made by Curl (1966), where the observed (natural data) length distributions exhibited more curvature on the plots than the modeled theoretical ones, so the proper basis for comparison of different cave settings is the use of all caves.

Although the exact values of $\mathrm{D}$ can not be interpreted directly by morphology of the caves, the larger fractal dimensions can be most probably interpreted by the ability of the caves to form complex longer passages, most probably along the initial fracture networks and also bedding planes. The more soluble and fractured rocks exhibit greater fractal dimensions, larger than one, and rocks with intergranular porosity (generally those with low porosity, low solubility and small degree of fracturing), show $\mathrm{D}$ below one. These variations probably have a natural source, and the differences between the dimensions are clearly observable, Larger values of $\mathrm{D}$ could be expected in anastomotic or networks caves, and lesser values in branchwork or single-passage caves (Palmer, 1991).

The physical causes of power law scaling and variations in fractal dimensions (power law exponents) are 
still poorly understood (Bonnet et al., 2001). The behaviour of fracture networks is believed to be caused by fractal fragmentation of blocks (Turcotte and Huang, 1995), which is scale-independent. Caves develop along the fractures and bedding planes, so they inherit the geometrical properties to some degree by dissolution of fractal networks. However, the processes which lead to the values of fractal dimensions of fracture networks and fractal behaviour of distribution of cave lengths and their dependence are still a challenge to be analyzed.

\section{ACKNOWLEDGMENTS}

The author thanks all the cave explorers for the efforts encountered during the cave measurements, France Šušteršič for debate, David J. Lowe for smoothing the
English version of the text and Lee Florea for useful comments which improved the quality of the text.

\section{REFERENCES}

Bonnet, E., Bour, O., Odling, N.E., Davy, P., Main, I., Cowie, P., Berkowitz, B., 2001: Scaling of fracture systems in geological media.- Reviews of Geophysics, 39, 3, 347-383.

Curl, R.L., 1966: Caves as a Measure of Karst. - Journal of Geology, 74, 5, 798-830.

Curl, R.L., 1986: Fractal Dimensions and Geometries of Caves.- Mathematical Geology, 18, 2, 765-783.

Curl, R.L., 1999: Entranceless and Fractal Caves Revisited.- In: Palmer, A.N., Palmer, M.V., Sasowsky, I.D., eds: Karst Modeling, Special Publication 5, Karst Water Institute, Charlottesville, Virginia, 183-185.

Feder, J., 1988: Fractals.- Plenum Press, p. 283, New York.

Ford, D. \& Williams, P., 2007: Karst Hydrogeology and Geomorphology.- John Wiley \& Sons, Ltd., p. 576.

Kusumayudha, S. B., Zen, M. T., Notosiswoyo, S., Gautama, R. S., 2000: Fractal analysis of the Oyo River, cave systems, and topography of the Gunungsewu karst area, central Java, Indonesia.- Hydrogeology Journal, 8, 271-278.

Laverty, M., 1987: Fractals in Karst.- Earth Surface Processes and Landforms, 12, 475-480.

Loucks, R.G., 1999: Paleocave Carbonate Reservoirs: Origins, Burial-Depth Modifications, Spatial Complexity, and Reservoir Implications.- AAPG Bulletin, 83, 11, 1795-1834.

Mandelbrot, B., 1983: The Fractal Geometry of Nature.W. H. Freeman \& Co., p. 468, New York, NY.
Palmer, A. N., 1991: Origin and morphology of limestone caves.- Geological Society of America Bulletin, 103, $1-21$.

Placer, L., 1999: Contribution to the macrotectonic subdivision of the border region between Southern Alps and External Dinarides.- Geologija 41, 191-221.

Poljak, M., 2000: Structural-Tectonic Map of Slovenia.Mladinska knjiga \& Geological Survey of Ljubljana, Ljubljana.

Šušteršič, F., 1983: Determination of the unknown cave passages length by means of fractal analysis.- In: Jančařik, A., ed.: Nove směri ve speleologii (New trends in speleology), 24.-28.10.1983 (Proceedings), 61-62.

Šušteršič, F., 1992: Delovni seznam jam jugovzhodne Slovenije.- Naše jame 34, 74-108.

Turcotte, D. L. \& Huang, J., 1995: Fractal Distributions in Geology, Scale Invariance, and Deterministic Chaos. In: Barton, C. C. and La Pointe, P. R. (eds): The Fractals in the Earth Sciences, 1-40.

Villemin T., Angelier, J., Sunwoo, C., 1995: Fractal Distribution of Fault Length and Offsets: Implications of Brittle Deformation Evaluation - The Lorraine Coal Basin. In: Barton, C. C. \& La Pointe, P. R. (eds): The Fractals in the Earth Sciences, 205-226. 
